\title{
STATEWIDE ADVOCACY
}

\author{
Janet Murguia \\ Executive Vice Chancellor for University Relations \\ University of Kansas
}

I've just completed my first experience with the state legislature after having worked in Washington for many years. I want to comment on the differences l've noticed at the state level, and then talk about our advocacy this session.

In Washington, D.C. you have 435 members of Congress and 100 senators. Our state government involves 125 legislators and 40 state senators. So, the scale is different at the state level. I was surprised by the partisan nature of state government. The very first week of the session, we heard comments about the Governor's address that could be called mean-spirited. In Washington, we didn't experience partisanship so early in the session. We have a three-party system in Kansas. Within the Republican Party there are the moderates and the conservatives and then we have the Democratic Party. Usually, a three-party split produces alliances between moderate Republicans and the Democrats. This session, the Democrats allied with the conservative Republicans. This kind of alliance is not based on ideological agreement - it is about politics. We saw an overwhelming level of political maneuvering from the very start of the legislative session and it continued throughout.

When I arrived at the University of Kansas (KU), one of my first jobs was governmental affairs and state relations. The budget dominated the legislative session. We worked hard to protect our interests in the budget. Our strategy had several components: keeping a united front with other Regents schools and kindergarten through $12^{\text {th }}$ grade $(\mathrm{K}-12)$ education, going directly to key legislators, and developing a grass roots campaign. It was clear to me that we had to work through the Board of Regents. A united front with other institutions was the best possibility. We made sure that we all used the same message. This takes a lot of discipline and trust building. It is not in the interest of KU to step apart from the other Regents institutions. We worked hard to build coalitions and get to know the key legislative leaders. We built constructive alliances with leaders in K-12 education. At the same time, we went to the public with our message. We held two events. One was at Silver Lake elementary school and included mascots from the six regents schools. The media picked up this story. We also did an event with the Kansas Chamber of Commerce and several business leaders who said they would support taxes that go to education.

When you are doing statewide advocacy, you've got to create a grass roots public campaign. Sometimes the issues are most real to the legislators when they go home and a constituent talks to them about their concerns. It is 
important to have letters and conversations. Some people were very creative. Kansas State University asked their football coach to send a letter to legislators. It is important to remind people that they have a role to play.

We must also continue to say that the state receives a good return for its investment. We must talk about economic development. Higher education is a partner with the state in creating a better destiny for us all. 